\title{
Review \\ Deregulation of p27 by oncogenic signaling and its prognostic significance in breast cancer
}

Angel Alkarain ${ }^{1}$ and Joyce Slingerland ${ }^{2}$

1Sunnybrook and Women's Health Sciences Centre, University of Toronto, Toronto, Ontario, Canada
2Braman Breast Cancer Institute, University of Miami School of Medicine, Miami, FL, USA

Corresponding author: Joyce Slingerland (e-mail: jslingerland@med.miami.edu)

Published: 21 October 2003

Breast Cancer Res 2004, 6:13-21 (DOI 10.1186/bcr722)

(c) 2004 BioMed Central Ltd (Print ISSN 1465-5411; Online ISSN 1465-542X)

\begin{abstract}
p27 is a key regulator of progression from $G 1$ to $S$ phase. Although the gene encoding p27 is rarely mutated in human cancers, p27 is functionally inactivated in a majority of human cancers through accelerated p27 proteolysis, through sequestration by cyclin D-cyclin-dependent kinase complexes and by cytoplasmic mislocalization. Here we review mechanisms whereby oncogenic activation of receptor tyrosine kinase and Ras pathways lead to accelerated p27 proteolysis and p27 mislocalization in cancer cells. The prognostic significance of p27 in human breast cancer is also reviewed.
\end{abstract}

Keywords: breast cancer, cell cycle, cyclin-dependent kinase, deregulation, p27

\section{Introduction}

G1 progression is governed by cyclin-dependent kinases (Cdks) [1-3]. The Cdks regulate biochemical pathways, or checkpoints, that integrate mitogenic and growth inhibitory signals and coordinate cell cycle transitions $[4,5]$. The Cdks are regulated by both activating and inhibitory phosphorylation, by cyclin binding and by two different families of Cdk inhibitors. In early $\mathrm{G} 1$ phase, mitogens increase D-type cyclins, which bind and activate Cdk4 and Cdk6 [6]. The subsequent activation of cyclin E and cyclin $\mathrm{A}-\mathrm{Cdk} 2$ complexes regulate $\mathrm{S}$ phase entry and progression. Two families of Cdk inhibitors regulate the cyclin-Cdk complexes $[2,7,8]$. The inhibitor of Cdk4 (INK4) family members, which include p15 INK4B, p16 $6^{\text {INK4A, }}$ p18INK4C, and p19INK4D, specifically bind Cdk4 and Cdk6 and inhibit cyclin $D$ association. Members of the kinase inhibitor protein (KIP) family, p21 ClP1, p2 $7^{\mathrm{Kip} 1}$, and p57 Kip2, bind and inhibit cyclin E-bound and cyclin A-bound Cdk2. Although p21 and p27 are major inhibitors of Cdk2, they also promote $\mathrm{G} 1$ progression by facilitating the assembly of cyclin D-Cdk4 and cyclin D-Cdk6 complexes $[9,10]$. In early G1, p27 assembles cyclin D1-Cdks in the cyto- plasm and this facilitates the import of cyclin D1 complexes into the nucleus.

\section{Regulation of the cell cycle inhibitor p27 KIP1}

p27 was discovered in cells arrested by transforming growth factor- $\beta$ (TGF- $\beta$ ), by contact inhibition, and by lovastatin [11-14]. p27 acts in G0 and early G1 to inhibit cyclin $\mathrm{E}-\mathrm{Cdk2}$. Assembly of cyclin D-Cdk complexes by p27 is activated in early $\mathrm{G} 1$ and involves changes in p27 phosphorylation [15]. Mitogenic growth factor signaling mediates a decrease in p27 protein levels. Whereas p27 mRNA concentrations are constant throughout the cell cycle, p27 concentrations are the highest in quiescent cells, decrease during G1 phase and are minimal in S phase [16]. p27 translation is maximal in quiescence and falls rapidly after exit from G0 $[16,17]$. p27 is also importantly regulated by proteolysis, with the p27 $t_{1 / 2}$ decreasing fivefold to eightfold with passage from $\mathrm{G} 0$ to $\mathrm{S}$ phase $[18,19]$.

\section{Transcriptional regulation}

Although p27 regulation occurs predominantly at the levels of translation and protein stability, transcriptional

$\mathrm{AFX}=$ acute lymphocytic leukaemia-1 fused gene from chromosome $\mathrm{X}$; Cdk = cyclin-dependent kinase; INK $=$ inhibitor of Cdk; KIP $=$ kinase inhibitor protein; MAPK = mitogen-activated protein kinase; MEK = MAPK kinase; PI3K = phosphoinositide 3-kinase; PKB = protein kinase B; PTEN $=$ phosphatase and tensin homolog deleted on chromosome 10; SCF = Skp1, Cul1, F-box protein; TGF- $\beta=$ transforming growth factor- $\beta$; $\mathrm{TSC} 2$ = tumor suppressor tuberin-2. 
regulation of $\mathrm{p} 27$ has been demonstrated. Normal quiescent T cells express high concentrations of p27 mRNA and protein, both of which decline rapidly after $\mathrm{T}$ cell activation [20]. Regulation of p27 mRNA concentrations also occurs after androgen depletion in breast cancer cells [21], in normal prostate tissue, and benign prostatic hyperplasia [22]. In melanoma cells, interleukin-6 signaling activates signal transduction and activators of transcription-3 (STAT3) and increases p27 mRNA [23]. The p27 promoter contains binding sites for several transcription factors including Sp1, cAMP-response element, Myb, $\mathrm{NF} \kappa \mathrm{B}$, and acute lymphocytic leukaemia-1 fused gene from chromosome $X$ (AFX). AFX is a forkhead transcription factor recently shown to activate p27 transcription [24]. Phosphorylation of AFX by protein kinase B (PKB) inactivates this transcription factor and might thereby decrease p27 transcription. The relevance of transcriptional regulation of p27 to human cancers is unclear because most reduction of p27 in human cancers is thought to occur through proteolysis (see below and [7]).

\section{Regulation of p27 localization}

p27 localization is also cell cycle regulated: p27 is nuclear in G0 and early G1 and appears transiently in the cytoplasm at the G1/S transition [25]. The nuclear import of p27 depends on a bipartite nuclear localization signal in the carboxy-terminal region of the protein [26]. Interaction of p27 with the nuclear pore protein NPAP60 $[27,28]$ is important in p27 nuclear import and might also regulate p27 export [27]. In response to mitogenic stimulation, at least part of the nuclear p27 pool undergoes nuclear export dependent on phosphorylation at serine 10 $[25,29,30]$. Human kinase interacting stathmin (hKis) can phosphorylate p27 at serine 10 [29]. p27 is bound to the exportin CRM1 in early G1, and binding of CRM1 to p27 increases with $G 1$ progression [25]. p27 contains a nuclear export signal (NES) whose mutation decreases p27-CRM1 binding, nuclear export, and p27 degradation [25]. Active CRM1-RanGTP-mediated nuclear export of p27 is linked to cytoplasmic proteolysis of p27 in early G1.

\section{Proteolytic degradation of p27}

p27 proteolysis is regulated by at least two distinct mechanisms. In early $\mathrm{G} 1$, mitogens seem to activate an exportlinked degradation mechanism that is followed in late $\mathrm{G} 1$ and $S$ phases by a cyclin E-Cdk2-dependent degradation of p27. The late $G 1$ and early S phase of p27 proteolysis is regulated by its phosphorylation at threonine 187 (T187) by cyclin E-Cdk2 [18,31-33]. Phosphorylation of p27 at T187 promotes the interaction of p27 with Skp2, the $\mathrm{F}$ box component of the SCFSkp2 (Skp1, Cul1, F-box protein) ubiquitin ligase. Once p27 phosphorylated on T187 is recognized by its SCF-type E3 ligase, composed of Skp1, Cul1, the F-box protein, Skp2 and Roc1, and the Cks1 cofactor [34-39], this complex then mediates the
Recent data from T187A knock-in and Skp2-/- mice also suggest that $\mathrm{p} 27$ proteolysis in early $\mathrm{G} 1$ is independent of T187 phosphorylation [19,40]. In early G1, growth factors stimulate p27 proteolysis in a manner independent of T187 phosphorylation and possibly also of Skp2 $[19,40]$. This initial mitogen-stimulated p27 degradation in early G1 might be linked to p27 export [25] and would allow an incremental activation of cyclin E-Cdk2 that is then followed by rapid, progressive Cdk2 activation as cyclin E-Cdk2 mediates T187 phosphorylation-dependent p27 degradation in late $\mathrm{G} 1$ and $\mathrm{S}$ phase.

\section{Deregulation of p27 in human cancers}

The human $p 27^{K I P 1}$ gene resides on chromosome $12 \mathrm{p} 13$. Loss of a single allele of $p 27^{K I P 1}$ confers increased susceptibility to chemical carcinogenesis in mice [41] and is not uncommon in a number of human malignancies [42-44]. However, $p 27^{K I P 1}$ does not follow Knudson's classic 'two-hit hypothesis' of tumor suppression: in tumors that show reduction to hemizygosity at the $p 27^{K I P 1}$ locus, silencing of the remaining allele is rare [42-44]. p27 is rarely mutated in human cancers. However, decreased concentrations of p27 protein might be implicated in human tumorigenesis or oncogenic progression in many human malignancies. Whereas p27 protein is expressed at high concentrations in all normal epithelia examined, including breast, prostate, ovary, skin, oral epithelium, and esophageal, gastric, colonic, and pulmonary mucosa, loss of p27 protein is frequently seen in carcinomas involving all these tissues [7]. Indeed, decreased concentrations of p27 protein have been observed in up to $60 \%$ of human carcinomas $[7,45]$. Multivariate analyses of p27 along with other known clinical and pathologic prognostic markers have shown that loss of p27 protein has independent prognostic potential in primary carcinoma of the breast, lung, colon, prostate, and many other malignancies including lymphomas, glioma, and melanoma [46-57] (reviewed in [7,45]). Although p27 function is rarely disrupted at the genetic level, it is frequently diminished in human cancers because of accelerated proteolysis, sequestration by other proteins, and cytoplasmic mislocalization. The next sections elaborate how the normal mechanisms of p27 regulation become disrupted in human cancers.

\section{Accelerated p27 proteolysis}

Most, if not all, cases of decreased p27 concentrations in human cancers are a reflection of accelerated proteolysis $[7,45]$. Lysates from a number of different tumor types show increased proteolytic activity toward p27 [47,52,58-60]. As noted above, a major mechanism of p27 proteolysis involves its recognition by SKP2, a component of the SCFSkp2 ubiquitin ligase. An association between decreased p27 protein and increased Skp2 concentrations has been observed in a subset of colorectal, prostatic, small cell lung, gastric, and oral carcinomas, and 
in lymphomas [60-65]. In oral squamous carcinoma, tumors with increased Skp2 always showed decreased p27 immunostaining. However, most oral cancers with low p27 did not show increased Skp2. Thus, causes other than increased Skp2 mediate p27 loss in a majority of cases [66]. Increased Skp2 might account for p27 loss in a minority of breast and prostate cancers with low p27 (J Slingerland and L Kapusta, unpublished work).

Loss of p27 function can be mediated by oncogenic activation of multiple receptor tyrosine kinase and signal transduction pathways. These are reviewed below.

\section{p27 sequestration by binding proteins}

In human cancers, p27 can also be sequestered by associated proteins that reduce its ability to bind and inhibit cyclin E-Cdk2. Some human lymphomas show the sequestration of p27 into active cyclin D1-Cdk4 complexes, potentially decreasing the p27 available for cyclin E-Cdk2 inhibition [67]. Overexpression of c-Myc can induce one or more heat-labile proteins that bind p27 and impair its binding to cyclin E-Cdk2 [68]. This effect is independent of p27 degradation and, in at least some cell types, is not due to increased cyclin D1 or D2. In other cancers, oncogenic activation of c-myc leads to p27 sequestration through the upregulation of cyclin D1 and D2 concentrations $[69,70]$. c-Myc also represses the expression of several negative cell cycle regulators including $p 15, p 21$, and $p 27$ (reviewed in [71]). c-Myc activation can arise through oncogenic mitogen signal transduction. Cyclin D1 and c-Myc expression are induced early in G1 after growth factor stimulation through the mitogen-activated protein kinase (MAPK) pathway [72-74]. Furthermore, activation of the phosphoinositide 3-kinase (PI3K)/PKB pathway increases the translation of c-Myc [50] and cyclin D1, and stabilizes D-type cyclins [75-77].

\section{Cytoplasmic mislocalization of p27}

Tumors that retain abundant p27 often show p27 mislocalization in the cytoplasm away from nuclear cyclin-Cdk targets [7]. Cytoplasmic localization would prevent p27 from binding and inhibiting nuclear cyclin-Cdk targets [78]. Cytoplasmic p27 is observed in certain lymphomas, in up to $55 \%$ of ovarian cancers, $80 \%$ of thyroid tumors, and $35 \%$ of colon cancers, with decreased p27 concentrations in the more poorly differentiated, advanced forms of these neoplasms [50,79-81]. Localization of p27 in the cytoplasm has also been described in $48 \%$ of esophageal dysplasias and $26 \%$ of Barrett's associated adenocarcinoma, and is associated in the latter with reduced survival [52].

We and others recently reported cytoplasmic mislocalization of p27 in up to $40 \%$ of primary human breast cancers [78,82-84]. These three studies showed that PKB phosphorylates p27 at T157 in its nuclear localization signal region. Cells with genetic loss of PTEN (the gene encoding
PTEN [phosphatase and tensin homolog deleted on chromosome 10]) or amplification of HER2/neu showed cytoplasmic mislocalization of p27 that was reversed by the PI3K inhibitor LY294002. Liang and colleagues [84] showed that p27 phosphorylation by PKB impaired the nuclear import of p27 in vitro. All three studies showed a consistent association between PKB activation and cytoplasmic p27 staining in primary breast cancers. Moreover, cytoplasmic p27, but not nuclear p27, isolated from primary cancers reacted with an anti-p27 antibody specific for phosphorylation on T157 [83]. Cytoplasmic p27 was correlated with tumor dedifferentiation (increased tumor grade) and poor prognosis [84]. Thus, oncogenic activation of the PI3K/PKB pathway and the PKB-dependent phosphorylation of p27 is probably one of the mechanisms underlying the cytoplasmic mislocalization of p27 in human cancers.

Although PKB-dependent T157 phosphorylation affected the subcellular localization of p27, transfection of constitutive PKB did not affect p27 protein concentrations in normal human mammary epithelial cells [84]. Activation of PKB and mislocalization of p27 were not statistically associated with decreased p27 concentrations in primary breast tumors. Thus, the increased p27 proteolysis observed after PI3K activation in many cell types might involve PI3K-dependent effectors other than PKB.

It is worth noting that cytoplasmic sequestration of p27 might not be equivalent to a loss of function of these Cdk inhibitors. Cytoplasmic p27 probably does not exist as a monomer. Cytoplasmic p27 might have functions other than Cdk inhibition; for example p27 might alter Ras function through the inactivation of GRB2 $[85,86]$. The phosphorylation event or events that alter the subcellular localization of p27 might also change KIP function.

\section{Regulation of p27 proteolysis by receptor tyrosine kinase and Ras signaling}

Ras effector pathways have key roles in p27 proteolysis [87-89]. The isolation of p27 and cloning of the p27 gene by the Reed group was facilitated by $\mathrm{p} 27$ upregulation by lovastatin, a potent inhibitor of Ras [12]. In fibroblasts, dominant-negative ras transfection increased p27 concentrations and caused G1 arrest; moreover, Ras-mediated activation of the MAPK-stimulated p27 proteolysis $[87,88]$. MAPK kinase (MEK1) transfection increased p27 degradation, and a MEK1 inhibitor, PD98059, abolished Ras effects on p27 [88,90]. Although p27 contains several MAPK consensus sites and MAPK can phosphorylate $\mathrm{p} 27$ in vitro and reduce its ability to bind Cdk2 $[88,91]$, it is not clear that p27 is a direct target of MAPK in vivo [88]. Constitutive Ras activation in epithelial cells can mislocalize p27 to the cytoplasm and increase p27 binding to Cdk6 [92]. This might reflect Ras-dependent PI3K/PKB activation. In some cell types, Ras-stimulated RhoA activation may mediate p27 proteolysis [72,93,94]. 
Several groups have shown that signaling dependent on Her2/ErbB2 and epidermal growth factor receptor can activate p27 proteolysis in a MEK/MAPK-dependent manner [95-97]. This is potentially of relevance to the accelerated p27 proteolysis observed in human breast and prostate cancers. Her2 overpression is observed in up to $30 \%$ of primary breast and other human cancers and is associated with increased tumor invasiveness and a poor patient outcome [98-100]. Primary breast cancers overexpressing Her2 exhibit decreased p27 concentrations [101,102]. Her2/ErbB2 overexpression can also upregulate c-Myc and D-type cyclins, and this might facilitate 27 sequestration in cyclin D-Cdk complexes and an associated increase in cyclinE-Cdk2 activity [103].

Constitutive expression of Bcr-Abl leads to the activation of p27 proteolysis and prevents the upregulation of p27 protein by TGF- $\beta$ and by serum and mitogen deprivation [104]. Bcr-Abl is constitutively active in chronic myeloid leukemia cells and constitutively activates several key regulators of survival, proliferation, and adhesion including Ras, Src, PI3K, and MAPK kinases [105-108].

\section{Activation of p27 proteolysis through the PI3K pathway}

In addition to effects of PI3K/PKB on p27 localization noted above, several studies suggest that the PI3K pathway also regulates p27 protein stability. Activation of the PI3K pathway decreases p27 concentrations, and PI3K inhibition by LY294002, by kinase-dead PKB/Akt, or by the overexpression of PTEN, a lipid phosphatase that opposes PI3K activation, have all been shown to increase p27 concentrations in certain cell types [109-111]. PI3K activation increased p27 proteolysis in hematopoietic cells expressing BCR/Abl, in prostate cancer cells, and in PTEN-null embryonic stem cells [112-114]. PTEN might inhibit p27 proteolysis through the repression of $S K P 2$, the F-box component of the SCFSkp2 ubiquitin ligase complex that mediates cyclin E-Cdk2-dependent p27 degradation. p27 concentrations were decreased and Skp2 was increased in PTEN-deficient mouse embryonic stem cells [115]. Restoring PTEN expression in a PTEN-deficient line and PI3K inhibition by LY294002 both decreased SKP2 gene expression. However, PTEN mediates arrest in G0, and thus the effect of PTEN on Skp2 concentrations in these studies might also reflect the destabilization of Skp2 protein associated with G1 arrest. Skp2 stability is dependent on the cell cycle, and its proteolysis is maximal in quiescent cells [116]. In human prostate, Skp2 protein concentrations are inversely correlated with p27 and the PTEN tumor suppressor protein [117].

p27 stability may also be linked to the PI3K/PKB pathway through the PKB-dependent phosphorylation of tuberin, a tumor suppresor encoded by the tuberous sclerosis complex 2 (TSC2) gene. The TSC2 gene is mutated in up to $50 \%$ of tuberous sclerosis patients. Tuberous slerosis family members develop benign hyperproliferative tumors with high frequency. TSC2 mutations are also seen in up to $30 \%$ of high-grade astrogliomas and in human lung cancers (reviewed in $[118,119]$ ). Loss of functional TSC2 or tuberin protein is associated with increased cyclin E-Cdk2, p27 mislocalization and decreased p27 due to p27 proteolysis that is independent of phosphorylation at T187 [120]. PKB has been recently shown to phosphorylate tuberin (reviewed in $[118,119]$ ) and this relieves its inhibitory action on mTOR. Inhibition of mTOR by rapamycin is known to stabilize p27 [121,122]. Thus, the increased stability of $p 27$ after inhibition of PI3K might result in part from inhibition of PKB, activation of TSC2 and subsequent inhibition of mTOR. It will be of interest to determine how downstream effectors of mTOR might regulate $\mathrm{p} 27$ proteolysis.

Although PI3K activation might decrease SKP2 transcription, and through PKB inactivate TSC2 and activate mTOR, the effects of this pathway on p27 stability are clearly dependent on cell type [84]. As noted earlier, activation of PKB alone might not suffice to trigger p27 degradation in some tumors. High PKB activity was not statistically associated with decreased p27 protein concentrations in primary breast cancers [84].

Activation of the PI3K effector PKB/Akt has been shown to phosphorylate p27 and to lead to its cytoplasmic sequestration in part by impaired nuclear import [78,82-84]. Cytoplasmic sequestration would tend to impair the cyclin E-Cdk2-dependent phase of p27 proteolysis because cyclin $\mathrm{E}-\mathrm{Cdk} 2$ is nuclear. Moreover, because nuclear p27 export in early G1 involves p27 phosphorylation, the cytoplasmic p27 that accumulates in PKB-activated cells might not be appropriately conditioned for export-linked proteolysis. Cytoplasmic p27 in these tumors might be relatively stable. Thus, the net effect of the oncogenic activation of the PI3K pathway on p27 stability might be complex in vivo, and the relative importance of PI3K effector pathways in certain cell types and concomitant changes in other signaling pathways might lead to important differences, dependent on cell type and tumor, in $\mathrm{p} 27$ regulation by the PI3K pathway.

\section{The prognostic role of p27 in human breast cancer}

Several groups have reported p27 studies in primary breast cancers. The first studies that identified p27 as an independent prognostic indicator involved three different breast cancer populations $[47,123,124]$. Tan and colleagues [47] studied the prognostic significance of p27 in 202 patients with breast cancers less than $1 \mathrm{~cm}$ in size. A low concentration of p27 protein, defined as less than $50 \%$ of tumor nuclei staining positively by immunohistochemistry, was associated with a 3.4-fold increased risk of death $(P=0.0306)$ on multivariate analysis. 
In a study of 168 unselected breast cancers, Catzavelos and colleagues [123] found that low p27 (less than 50\% of tumor nuclei staining positive) was a strong independent predictor of reduced disease-free survival with a 2.7-fold increased risk of disease relapse $(P=0.017)$. Breast tumors with low p27 were shown to have high cyclinE/Cdk2 activity $[123,125]$.

Porter and colleagues [124] assayed p27 in the primary breast cancers of 278 women under the age of 45 years. Decreased p27 concentration was a significant independent predictor of poor overall survival (relative risk 2.7; $P=0.01$ ). Patients whose breast cancers showed both low p27 and elevated cyclin E proteins had the highest mortality, but both of these factors were significant on multivariate analysis. An inverse correlation between cyclin $\mathrm{E}$ and p27 concentrations has been observed in breast cancers [125], whereas increased concentrations of cyclin D1 were associated with both higher p27 concentrations and low tumor grade in another study [46].

A decrease in p27 concentrations might precede tumor invasion [123,126,127], and invasive lobular carcinoma seems to show increased p27 staining compared with invasive ductal carcinoma $[128,129]$. Two studies have also found an association between low p27 together with Her2/neu overexpression and reduced disease-free survival $[101,102]$.

Several subsequent studies of breast cancer patients have also shown that the frequent decrease in p27 correlates with poor patient outcome. These studies have confirmed the correlation between low p27 and high tumor grade, negative estrogen receptor status and low cyclin D1 expression, and some have shown that low p27 is correlated with increased Ki67 or a high S-phase fraction [102,125,130-134]. Whereas several studies confirm the independent prognostic significance of p27 [46,131,132, 135], others failed to find $p 27$ to be prognostically significant on multivariate analysis $[102,130,133,136]$. The Gillet study used a different scoring method from most [130]. A study of 198 breast cancer patients with a 17-year median follow-up concluded that tissue expression of p27 might be important for predicting 5-year, but not longer (more than 10-year) breast-cancer-specific survival [136]. This observation was not supported by our study in node negative breast cancers (see below).

Although node-negative breast cancers have a better prognosis than node-positive cancers, up to $30 \%$ of nodenegative patients suffer recurrence and death from breast cancer. It would be of value to define variables other than traditional histopathologic features (size, lymphovascular invasion, tumor grade, and estrogen receptor status) to help define which patients merit aggressive treatment and who could safely be spared adjuvant chemotherapy. The
Porter study showed that p27 was prognostic in the nodenegative patient group, but this lacked statistical power on multivariate analysis [124]. Wu and colleagues analyzed 97 patients with node-negative breast cancer. A decreased p27 concentration (less than 50\% of tumor nuclei positive) was an independent prognostic factor with relative risks of $5.7(P=000.1)$ and $3.7(P=0.049)$ for disease-free and overall survival, respectively [132].

In an analysis of 118 Ashkenazi Jewish women with nodenegative disease, a decreased p27 concentration conferred a 10-fold increased risk of disease relapse $(P=0.03)$ [135]. Paradoxically, Barbareschi and colleagues [137] found high p27 concentrations to be prognostically significant in their node-negative subset analysis. We have recently completed a large study of 1057 prospectively accrued node-negative breast cancer patients with a median follow-up of 9 years. Decreased p27 concentration was strongly correlated with estrogenreceptor-negative status and high grade. With a scoring cut-off of $25 \%$ to define low/high p27 values, low p27 (less than $25 \%$ of tumor cells positive) was an independent prognostic factor with a relative risk of $1.54(P=0.02)$ and this was durable over the extended median follow-up of 9 years (C Catzavelos and J Slingerland, manuscript in preparation). It is noteworthy that two prostate cancer studies have also used the lower threshold of p27 (less than $25 \%$ ) to define the worst prognostic group [53,54].

The failure to find $\mathrm{p} 27$ to be of prognostic significance in some of the more recent reports might reflect differences in tumor fixation, p27 staining and scoring methods, and the prolonged storage time of the archival tumor blocks used in these studies. In our attempts to stain p27 in more than 800 tumors recovered during the 1970s, we needed to increase antigen retrieval; even with high concentrations of antibody, tumor staining was variable and unreliable ( $M$ Dowsett, A Alkarain and J Slingerland, unpublished work). Prolonged storage of tumor blocks and fixation differences might account for the different results published recently. For p27 to become part of the panel of prognostic tests applied in the routine evaluation of breast cancers at diagnosis, it will be necessary to establish a uniform methodology for tumor processing, staining, and scoring.

As noted above, p27 is detectable in the cytoplasm of up to $40 \%$ of primary breast cancers, and this has been consistently associated with PKB/Akt activation. Cytoplasmic p27 was correlated with tumor de-differentiation (increased tumor grade) and poor survival [84]. The presence of cytoplasmic p27 was not statistically correlated with low concentrations of nuclear p27 protein. Some cancers showed both decreased p27 concentrations and cytoplasmic p27 localization, and these had the lowest survival rate, whereas those with high p27 concentrations and nuclear localization fared the best [84]. Thus, inde- 
pendent mechanisms might regulate the cytoplasmic mislocalization of p27 in some tumors and its accelerated degradation in others. p27 proteolysis and mislocalization are regulated by major downstream effectors of receptor tyrosine kinases, including PKB and MAPK. It will be of interest to determine the additional pathways that predicate one effect or the other, or, in some tumors, the coexistence of both p27 protein loss and cytoplasmic mislocalization. Taking into account the localization of p27 might be an additional variable that adds to the prognostic potential of p27 evaluation in breast cancers.

\section{Conclusion}

Since its discovery and cloning a decade ago $[11,12,14,138]$, p27 has proved to be ubiquitously expressed and a frequent target for deregulation in cancer. The loss of a single p27 allele is not infrequent in human cancers. In mice, haploinsufficiency for p27 mediates an increased susceptibility to carcinogens. p27 function is impaired in a majority of human cancers through accelerated proteolysis, sequestration by other proteins, and an imbalance of mechanisms regulating nuclear import and export. Decreased p27 protein concentration is associated with cancer cell dedifferentiation and poor patient outcomes in a majority of breast cancer studies including node-negative disease. The broad clinical application of p27 in the prognostic evaluation of breast cancer will require the development of a consensus on methods of tumor fixation staining and scoring. As the growth factor signaling pathways that regulate p27 in normal cells and lead to its deregulation in cancers are elucidated, it is to be hoped that therapeutic avenues for the restoration of p27 function will emerge.

\section{Competing interests}

None declared.

\section{References}

1. Sherr CJ: G1 phase progression: cycling on cue. Cell 1994, 79: $551-555$.

2. Sherr CJ, Roberts JM: Inhibitors of mammalian G1 cyclindependent kinases. Genes Dev 1995, 9:1149-1163.

3. Reed SI, Bailly E, Dulic V, Hengst L, Resnitzky D, Slingerland J: G1 control in mammalian cells. J Cell Sci Supp/ 1994, 18:69-73.

4. Murray AW: Creative blocks: cell cycle checkpoints and feedback controls. Nature 1992, 359:599-604.

5. Hartwell L: Defects in a cell cycle checkpoint may be responsible for the genomic instability of cancer cells. Cell 1992, 71: 543-546.

6. Morgan DO: Principles of CDK regulation. Nature 1995, 374: 131-134.

7. Slingerland J, Pagano M: Regulation of the cdk inhibitor p27 and its deregulation in cancer. J Cell Physio/ 2000, 183:10-17.

8. Sherr CJ, Roberts JM: CDK inhibitors: positive and negative regulators of G1-phase progression. Genes Dev 1999, 13: 1501-1512.

9. LaBaer J, Garrett MD, Stevenson LF, Slingerland JM, Sandhu C, Chou HS, Fattaey A, Harlow E: New functional activities for the p21 family of CDK inhibitors. Genes Dev 1997, 11:847-862.

10. Cheng M, Olivier P, Diehl JA, Fero M, Roussel MF, Roberts JM, Sherr CJ: The p21 ${ }^{\text {Cip1 } 1}$ and p27Kip1 CDK 'inhibitors' are essential activators of cyclin D-dependent kinases in murine fibroblasts. EMBO J 1999, 18:1571-1583.
11. Koff A, Ohtsuki M, Polyak K, Roberts JM, Massagué J: Negative regulation of $\mathrm{G} 1$ in mammalian cells: inhibition of cyclin $\mathrm{E}$ dependent kinase by TGF- $\beta$. Science 1993, 260:536-539.

12. Hengst L, Dulic V, Slingerland JM, Lees E, Reed SI: A cell cycleregulated inhibitor of cyclin-dependent kinases. Proc Natl Acad Sci USA 1994, 91:5291-5295.

13. Polyak K, Kato JY, Solomon MJ, Sherr CJ, Massagué J, Roberts JM, Koff A: p27Kip1, a cyclin-Cdk inhibitor, links transforming growth factor- $\beta$ and contact inhibition to cell cycle arrest. Genes Dev 1994, 8:9-22.

14. Slingerland JM, Hengst L, Pan CH, Alexander D, Stampfer MR, Reed SI: A novel inhibitor of cyclin-Cdk activity detected in transforming growth factor $\beta$-arrested epithelial cells. Mol Cell Biol 1994, 14:3683-3694.

15. Ciarallo S, Subramaniam V, Hung W, Lee JH, Kotchetkov R, Sandhu C, Milic A, Slingerland JM: Altered p27 Kip1 phosphorylation, localization, and function in human epithelial cells resistant to transforming growth factor $\beta$-mediated $\mathrm{G}_{1}$ arrest. $\mathrm{Mol}$ Cell Biol 2002, 22:2993-3002.

16. Hengst L, Reed SI: Translational control of p27Kip1 accumulation during the cell cycle. Science 1996, 271:1861-1864.

17. Millard SS, Yan JS, Nguyen H, Pagano M, Kiyokawa H, Koff A: Enhanced ribosomal association of p27 Kip1 $\mathrm{mRNA}$ is a mechanism contributing to accumulation during growth arrest. $J$ Biol Chem 1997, 272:7093-7098.

18. Pagano M, Tam SW, Theodoras AM, Beer-Romero P, Del Sal G, Chau V, Yew PR, Draetta GF, Rolfe M: Role of the ubiquitin-proteasome pathway in regulating abundance of the cyclin-dependent kinase inhibitor p27. Science 1995, 269: $682-685$.

19. Malek NP, Sundberg H, McGrew S, Nakayama K, Kyriakidis TR Roberts JM: A mouse knock-in model exposes sequential proteolytic pathways that regulate $\mathrm{p} 27^{\mathrm{Kip} 1}$ in $\mathrm{G} 1$ and $\mathrm{S}$ phase. Nature 2001, 413:323-327.

20. Kwon TK, Nagel JE, Buchholz MA, Nordin AA: Characterization of the murine cyclin-dependent kinase inhibitor gene p27 Kip1. Gene 1996, 180:113-120.

21. Menjo M, Kaneko Y, Ogata E, Ikeda K, Nakanishi M: Critical role for p27 Kip1 in cell cycle arrest after androgen depletion in mouse mammary carcinoma cells (SC-3). Oncogene 1998, 17: 2619-2627.

22. Cordon-Cardo C, Koff A, Drobnjak M, Capodieci P, Osman I, Millard SS, Gaudin PB, Fazzari M, Zhang ZF, Massagué J, Scher $\mathrm{HI}$ : Distinct altered patterns of p27KIP1 gene expression in benign prostatic hyperplasia and prostatic carcinoma. J Nat Cancer Inst 1998, 90:1284-1291.

23. Kortylewski M, Heinrich PC, Mackiewicz A, Schniertshauer U, Klingmuller U, Nakajima K, Hirano T, Horn F, Behrmann I: Interleukin- 6 and oncostatin M-induced growth inhibition of human A375 melanoma cells is STAT-dependent and involves upregulation of the cyclin-dependent kinase inhibitor p27/ Kip1. Oncogene 1999, 18:3742-3753.

24. Medema RH, Kops GJ, Bos JL, Burgering BM: AFX-like Forkhead transcription factors mediate cell-cycle regulation by Ras and PKB through p27 kip1. Nature 2000, 404:782-787.

25. Connor MK, Kotchetkov R, Cariou S, Resch A, Lupetti R, Beniston RG, Melchior F, Hengst L, Slingerland JM: CRM1/Ran-mediated nuclear export of p27 Kip1 involves a nuclear export signal and links p27 export and proteolysis. Mol Biol Cell 2003, 14:201-213.

26. Zeng $Y$, Hirano K, Hirano M, Nishimura J, Kanaide H: Minimal requirements for the nuclear localization of p27 Kip1, a cyclindependent kinase inhibitor. Biochem Biophys Res Commun 2000, 274:37-42.

27. Guan T, Kehlenbach RH, Schirmer EC, Kehlenbach A, Fan F, Clurman BE, Arnheim N, Gerace L: Nup50, a nucleoplasmically oriented nucleoporin with a role in nuclear protein export. $\mathrm{Mol}$ Cell Biol 2000, 20:5619-5630.

28. Muller D, Thieke K, Burgin A, Dickmanns A, Eilers M: Cyclin E mediated elimination of $\mathrm{p} 27$ requires its interaction with the nuclear pore associated protein mNPAP60. EMBO J 2000, 19: 2168-2180.

29. Boehm M, Yoshimoto T, Crook MF, Nallamshetty S, True A, Nabel GJ, Nabel EG: A growth factor-dependent nuclear kinase phosphorylates $\mathrm{p} 27^{\mathrm{Kip} 1}$ and regulates cell cycle progression. EMBO J 2002, 21:3390-3401.

30. Rodier G, Montagnoli A, Di Marcotullio L, Coulombe P, Draetta GF, Pagano M, Meloche S: p27 cytoplasmic localization is reg- 
ulated by phosphorylation on Ser10 and is not a prerequisite for its proteolysis. EMBO J 2001, 20:6672-6682.

31. Sheaff RJ, Groudine M, Gordon M, Roberts JM, Clurman BE: Cyclin E-CDK2 is a regulator of p27 ${ }^{\text {Kip } 1 . ~ G e n e s ~ D e v ~ 1997, ~ 11: ~}$ 1464-1478.

32. Vlach J, Hennecke S, Amati B: Phosphorylation-dependent degradation of the cyclin-dependent kinase inhibitor p27. EMBO J 1997, 16:5334-5344

33. Montagnoli A, Fiore F, Eytan E, Carrano AC, Draetta GF, Hershko A, Pagano M: Ubiquitination of p27 is regulated by Cdk-dependent phosphorylation and trimeric complex formation. Genes Dev 1999, 13:1181-1189.

34. Ohta T, Michel JJ, Schottelius AJ, Xiong Y: ROC1, a homolog of APC11, represents a family of cullin partners with an associated ubiquitin ligase activity. Mol Cell 1999, 3:535-541.

35. Carrano AC, Eytan E, Hershko A, Pagano M: SKP2 is required for ubiquitin-mediated degradation of the CDK inhibitor p27. Nat Cell Biol 1999, 1:193-199.

36. Tsvetkov LM, Yeh KH, Lee SJ, Sun H, Zhang H: p27Kip1 ubiquitination and degradation is regulated by the SCFSkp2 complex through phosphorylated Thr187 in p27. Curr Biol 1999, 9:661664.

37. Sutterluty $\mathrm{H}$, Chatelain E, Marti A, Wirbelauer C, Senften M, Muller $\mathrm{U}, \mathrm{Krek} \mathrm{W}$ : p45SKP2 promotes $\mathrm{p} 27^{\mathrm{Kip} 1}$ degradation and induces S phase in quiescent cells. Nat Cell Biol 1999, 1:207-214.

38. Spruck C, Strohmaier H, Watson M, Smith AP, Ryan A, Krek TW, Reed SI: A CDK-independent function of mammalian Cks1: targeting of SCFSkp2 to the CDK inhibitor p27 Kip1. Mol Cell 2001, 7:639-650.

39. Ganoth D, Bornstein G, Ko TK, Larsen B, Tyers M, Pagano M, Hershko $A$ : The cell-cycle regulatory protein $\mathrm{Cks} 1$ is required for SCFSkp2-mediated ubiquitinylation of p27. Nat Cell Biol 2001, 3:321-324.

40. Hara T, Kamura T, Nakayama K, Oshikawa K, Hatakeyama S, Nakayama Kl: Degradation of p27 Kip1 at the G0-G1 transition mediated by a Skp2-independent ubiquitination pathway. $J$ Biol Chem 2001, 276:48937-48943.

41. Fero ML, Randel E, Gurley KE, Roberts JM, Kemp CJ: The murine gene $\mathrm{p} 27^{K i p 1}$ is haplo-insufficient for tumour suppression. Nature 1998, 396:177-180.

42. Kawamata N, Morosetti R, Miller CW, Park D, Spirin KS, Nakamaki T, Takeuchi S, Hatta Y, Simpson J, Wilczynski S, Young YL, Bartram CR, Koeffler HP: Molecular analysis of the cyclindependent kinase inhibitor gene $p 27^{K i p 1}$ in human malignancies. Cancer Res 1995, 55:2266-2269.

43. Pietenpol JA, Bohlander SK, Sato Y, Papadopoulos N, Liu B, Friedman C, Trask BJ, Roberts JM, Kinzler KW, Rowley JD, Vogelstein B: Assignment of human $p 27^{K i p 1}$ gene to $12 p 13$ and its analysis in luekemias. Cancer Res 1995, 55:1206-1210.

44. Ponce-Castaneda MV, Lee MH, Latres E, Polyak K, Lacombe L, Montgomery K, Mathew S, Krauter K, Sheinfeld J, Massagué J, Cordon-Cardo C: p27kip1: chromosomal mapping to 12p12$12 p 13.1$ and absence of mutations in human tumours. Cancer Res 1995, 55:1211-1214.

45. Viglietto G, Fusco A: Understanding $\mathbf{p} 27^{\mathrm{kip} 1}$ deregulation in cancer: down-regulation or mislocalization? Cell Cycle 2002, 1:394-400.

46. Fredersdorf S, Burns J, Milne AM, Packham G, Fallis L, Gillett CE, Royds JA, Peston D, Hall PA, Hanby AM, Barnes DM, Shousha S, O'Hare MJ, Lu X: High level expression of p27kip1 and cyclin D1 in some human breast cancer cells: inverse correlation between the expression of p27 $7^{\mathrm{kip} 1}$ and degree of malignancy in human breast and colorectal cancers. Proc Natl Acad Sci USA 1997, 94:6380-6385.

47. Tan P, Cady B, Wanner M, Worland P, Cukor B, Magi-Galluzzi C, Lavin $P$, Draetta G, Pagano M, Loda M: The cell cycle inhibitor p27 is an independent prognostic marker in small (T1a,b) invasive breast carcinomas. Cancer Res 1997, 57:1259-1263.

48. Guo Y, Sklar GN, Borkowski A, Kyprianou N: Loss of the cyclindependent kinase inhibitor p27kip1 protein in human prostate cancer correlates with tumor grade. Clin Cancer Res 1997, 3: 2269-2274.

49. Piva R, Cavalla P, Bortolotto S, Cordera S, Richiardi P, Schiffer D: p27/kip1 expression in human astrocytic gliomas. Neurosci Lett 1997, 234:127-130.

50. Ciaparrone M, Yamamoto H, Yao Y, Sgambato A, Cattoretti G, Tomita N, Monden T, Rotterdam H, Weinstein IB: Localization and expression of $\mathrm{p} 27^{\mathrm{KIP} 1}$ in multistage colorectal carcinogenesis. Cancer Res 1998, 58:114-122.

51. Cote RJ, Shi Y, Groshen S, Feng AC, Cordon-Cardo C, Skinner D, Lieskovosky G: Association of p27 Kip1 levels with recurrence and survival in patients with stage $\mathrm{C}$ prostate carcinoma. $J$ Natl Cancer Inst 1998, 90:916-920.

52. Singh SP, Lipman J, Goldman H, Ellis FH, Aizenman L, Cangi MG, Signoretti S, Chiaur DS, Pagano M, Loda M: Loss or altered subcellular localization of p27 in Barrett's associated adenocarcinoma. Cancer Res 1998, 58:1730-1735.

53. Tsihlias J, Kapusta LR, DeBoer G, Morava-Protzner I, Zbieranowski I, Bhattacharya N, Catzavelos GC, Klotz LH, Slingerland $\mathrm{JM}$ : Loss of cyclin dependent kinase inhibitor $\mathrm{p} 27^{\mathrm{Kip} 1}$ is a novel prognostic factor in localized human prostate adenocarcinoma. Cancer Res 1998, 58:542-548.

54. Yang RM, Naitoh J, Murphy M, Wang HJ, Philipson J, deKernion JB, Loda M, Reiter RE: Low p27 expression predicts poor disease-free survival in patients with prostate cancer. $J$ Urol 1998, 159:941-945.

55. Catzavelos C, Tsao MS, DeBoer G, Bhattacharya N, Shepherd F, Slingerland JM: Reduced expression of the cell cycle inhibitor p27 Kip1 in non-small cell lung carcinoma: a potential prognostic factor independent of ras. Cancer Res. 1999, 59:684-688.

56. Piva R, Cancelli I, Cavalla P, Bortolotto S, Dominguez J, Draetta GF, Schiffer D: Proteasome-dependent degradation of p27/ kip1 in gliomas. J Neuropathol Exp Neurol 1999, 58:691-696.

57. Mizumatsu S, Tamiya T, Ono Y, Abe T, Matsumoto K, Furuta T, Ohmoto T: Expression of cell cycle regulator p2 $7^{\text {Kip } 1}$ is correlated with survival of patients with astrocytoma. Clin Cancer Res 1999, 5:551-557.

58. Loda M, Cukor B, Tam SW, Lavin P, Fiorentino M, Draetta GF, Jessup JM, Pagano $\mathrm{M}$ : Increased proteasome-dependent degradation of the cyclin- dependent kinase inhibitor p27 in aggressive colorectal carcinomas. Nat Med 1997, 3:231-234.

59. Esposito V, Baldi A, De Luca A, Groger AM, Loda M, Giordano GG, Caputi M, Baldi F, Pagano M, Giordano A: Prognostic role of the cyclin-dependent kinase inhibitor p27 in non-small cell lung cancer. Cancer Res 1997, 57:3381-3385.

60. Chiarle R, Budel L, Skolnik J, Frizzera G, Chilosi M, Corato A, Pizzolo G, Magidson J, Montagnoli A, Pagano M, Maes B, DeWolf $C$, Inghirani G: Increased proteasome degradation of cyclindependent kinase inhibitor p27 is associated with a decreased overall survival in mantle cell lymphoma. Blood (in press).

61. Hershko D, Bornstein G, Ben Izhak O, Carrano A, Pagano M, Krausz MM, Hershko A: Inverse relation between levels of p27 Kip1 and of its ubiquitin ligase subunit Skp2 in colorectal carcinomas. Cancer 2001, 91:1745-1751.

62. Kudo Y, Kitajima S, Sato S, Miyauchi M, Ogawa I, Takata T: High expression of S-phase kinase-interacting protein 2 , human $\mathrm{F}$ box protein, correlates with poor prognosis in oral squamous cell carcinomas. Cancer Res 2001, 61:7044-7047.

63. Latres E, Chiarle R, Schulman BA, Pavletich NP, Pellicer A, Inghirami G, Pagano M: Role of the F-box protein Skp2 in lymphomagenesis. Proc Natl Acad Sci USA 2001, 98:2515-2520.

64. Yokoi S, Yasui K, Saito-Ohara F, Koshikawa K, lizasa T, Fujisawa T, Terasaki T, Horii A, Takahashi T, Hirohashi S, Inazawa J: A novel target gene, SKP2, within the 5p13 amplicon that is frequently detected in small cell lung cancers. Am J Patho/ 2002, 161:207-216.

65. Masuda TA, Inoue H, Sonoda H, Mine S, Yoshikawa $Y$, Nakayama $\mathrm{K}$, Nakayama K, Mori M: Clinical and biological significance of S-phase kinase-associated protein 2 (Skp2) gene expression in gastric carcinoma: modulation of malignant phenotype by Skp2 overexpression, possibly via p27 proteolysis. Cancer Res 2002, 62:3819-3825.

66. Gstaiger M, Jordan R, Lim M, Catzavelos C, Mestan J, Slingerland $\mathrm{J}$, Krek W: Skp2 is oncogenic and overexpressed in human cancers. Proc Natl Acad Sci USA 2001, 98:5043-5048.

67. Sanchez-Beato M, Camacho Fl, Martinez-Montero JC, Saez Al, Villuendas R, Sanchez-Verde L, Garcia JF, Piris MA: Anomalous high p27/KIP1 expression in a subset of aggressive B-cell lymphomas is associated with cyclin D3 overexpression. p27/KIP1-cyclin D3 colocalization in tumor cells. Blood 1999, 94:765-772.

68. Vlach J, Hennecke S, Alevizopoulos K, Conti D, Amati B: Growth arrest by the cyclin-dependent kinase inhibitor p27 $7^{\mathrm{Kip} 1}$ is abrogated by c-Myc. EMBO J 1996, 15:6595-6604. 
69. Bouchard C, Thieke K, Maier A, Saffrich R, Hanley-Hyde J, Ansorge W, Reed S, Sicinski P, Bartek J, Eilers M: Direct induction of cyclin D2 by Myc contributes to cell cycle progression and sequestration of p27. EMBO J 1999, 18:5321-5333.

70. Perez-Roger I, Kim SH, Griffiths B, Sweing A, Land H: Cyclins D1 and D2 mediate Myc-induced proliferation via sequestration of p27 Kip1 and p21Cip1. EMBO J 1999, 18:5310-5320.

71. Gartel AL, Shchors K: Mechanisms of c-myc-mediated transcriptional repression of growth arrest genes. Exp Cell Res 2003, 283:17-21.

72. Weber JD, Hu W, Jefcoat SC Jr, Raben DM, Baldassare JJ: Rasstimulated extracellular signal-related kinase 1 and RhoA activities coordinate platelet-derived growth factor-induced G1 progression through the independent regulation of cyclin D1 and p27. J Biol Chem 1997, 272:32966-32971.

73. Balmanno K, Cook SJ: Sustained MAP kinase activation is required for the expression of cyclin D1, p21Cip1 and a subset of AP-1 proteins in CCL39 cells. Oncogene 1999, 18: 3085-3097.

74. Sears RC, Nevins JR: Signaling networks that link cell proliferation and cell fate. J Biol Chem 2002, 277:11617-11620.

75. Alt JR, Cleveland JL, Hannink M, Diehl JA: Phosphorylationdependent regulation of cyclin D1 nuclear export and cyclin D1-dependent cellular transformation. Genes Dev 2001, 14: 3102-3114.

76. Diehl JA, Cheng M, Roussel MF, Sherr CJ: Glycogen synthase kinase- $3 \beta$ regulates cyclin D1 proteolysis and subcellular localization. Genes Dev 1998, 12:3499-3511.

77. Fiorentino M, Altimari A, D'Errico A, Cukor B, Barozzi C, Loda M, Grigioni WF: Acquired expression of p27 is a favorable prognostic indicator in patients with hepatocellular carcinoma. Clin Cancer Res 2000, 10:3966-3972.

78. Blain SW, Massagué J: Breast cancer banishes p27 from nucleus. Nat Med 2002, 8:1076-1078.

79. Baldassarre G, Belletti B, Bruni P, Boccia A, Trapasso F, Pentimalli F, Barone MV, Chiappetta G, Vento MT, Spiezia S, Fusco A, Viglietto G: Overexpressed cyclin D3 contributes to retaining the growth inhibitor p27 in the cytoplasm of thyroid tumor cells. J Clin Invest 1999, 104:865-874.

80. Masciullo V, Sgambato A, Pacilio C, Pucci B, Ferrandina G, Palazzo J, Carbone A, Cittadini A, Mancuso S, Scambia G, Giordano $A$ : Frequent loss of expression of the cyclin-dependent kinase inhibitor p27 in epithelial ovarian cancer. Cancer Res 1999, 59:3790-3794.

81. Li JQ, Miki H, Wu F, Saoo K, Nishioka M, Ohmori M, Imaida K: Cyclin A correlates with carcinogenesis and metastasis, and p27kip1 correlates with lymphatic invasion, in colorectal neoplasms. Hum Pathol 2002, 33:1006-1015.

82. Shin I, Yakes FM, Rojo F, Shin NY, Bakin AV, Baselga J, Arteaga $\mathrm{CL}$ : PKB/Akt mediates cell-cycle progression by phosphorylation of p27 Kip1 at threonine 157 and modulation of its cellular localization. Nat Med 2002, 8:1145-1152.

83. Viglietto G, Motti ML, Bruni P, Melillo RM, D'Alessio A, Califano D, Vinci F, Chiappetta G, Tsichlis P, Bellacosa A, Fusco A, Santoro $M$ : Cytoplasmic relocalization and inhibition of the cyclindependent kinase inhibitor p27Kip1 by PKB/Akt-mediated phosphorylation in breast cancer. Nat Med 2002, 8:11361144.

84. Liang J, Zubovitz J, Petrocelli T, Kotchetkov R, Connor MK, Han K, Lee JH, Ciarallo S, Catzavelos C, Beniston R, Franssen E, Slingerland JM: PKB/Akt phosphorylates p27, impairs nuclear import of p27 and opposes p27-mediated G1 arrest. Nat Med 2002, 8:1153-1160.

85. Moeller J, Head D, Sheaff RJ: p27Kip1 inhibition of GRB2-SOS formation can regulate Ras activation. Mol Cell Biol 2003, 23:3735-3752

86. McAllister SS, Becker-Hapak M, Pintucci G, Pagano M, Dowdy SF: Novel p27kip1 C-terminal scatter domain mediates Racdependent cell migration independent of cell cycle arrest functions. Mol Cell Biol 2003, 23:216-228.

87. Aktas $\mathrm{H}$, Cai $\mathrm{H}$, Cooper $\mathrm{GM}$ : Ras links growth factor signaling to the cell cycle machinery via regulation of cyclin D1 and the Cdk inhibitor p27KIP1. Mol Cell Biol 1997, 17:3850-3857.

88. Kawada M, Yamagoe S, Murakami Y, Suzuki K, Mizuno S, Uehara $Y$ : Induction of p27Kip1 degradation and anchorage independence by Ras through the MAP kinase signaling pathway. Oncogene 1997, 15:629-637.
89. Takuwa N, Takuwa Y: Ras activity late in G1 phase required for p27kip1 downregulation, passage through the restriction point, and entry into S phase in growth factor-stimulated NIH 3T3 fibroblasts. Mol Cell Biol 1997, 17:5348-5358.

90. Hoshino R, Tanimura S, Watanabe K, Kataoka T, Kohno M: Blockade of the extracellular signal-regulated kinase pathway induces marked G1 cell cycle arrest and apoptosis in tumor cells in which the pathway is constitutively activated: up-regulation of p27Kip1. J Biol Chem 2001, 276:2686-2692.

91. Alessandrini A, Chiaur DS, Erikson R, Pagano M: Regulation of the cyclin-depedent kinase inhibitor p27 by degradation and phosphorylation. Leukemia 1997, 11:342-345.

92. Liu X, Sun Y, Ehrlich M, Lu T, Kloog Y, Weinberg RA, Lodish HF, Henis YI: Disruption of TGF- $\beta$ growth inhibition by oncogenic ras is linked to p27Kip1 mislocalization. Oncogene 2000, 19: 5926-5935.

93. Hirai A, Nakamura S, Noguchi Y, Yasuda T, Kitagawa M, Tatsuno I, Oeda T, Tahara K, Terano T, Narumiya S, Kohn LD, Saito Y: Geranylgeranylated rho small GTPase(s) are essential for the degradation of $\mathrm{p} 27^{\mathrm{Kip} 1}$ and facilitate the progression from $\mathrm{G} 1$ to $\mathbf{S}$ phase in growth-stimulated rat FRTL-5 cells. J Biol Chem 1997, 272:13-16.

94. Hu W, Bellone CJ, Baldassare JJ: RhoA stimulates p27Kip degradation through its regulation of cyclin E/CDK2 activity. $J$ Biol Chem 1999, 274:3396-3401.

95. Lenferink AE, Busse D, Flanagan WM, Yakes FM, Arteaga CL: ErbB2/neu kinase modulates cellular p27 Kip1 and cyclin D1 through multiple signaling pathways. Cancer Res 2001, 61: 6583-6591.

96. Yang HY, Zhou BP, Hung MC, Lee MH: Oncogenic signals of HER-2/neu in regulating the stability of the cyclin-dependent kinase inhibitor p27. J Biol Chem 2000, 275:24735-24739.

97. Donovan JC, Milic A, Slingerland JM: Constitutive MEK/MAPK activation leads to p27Kip1 deregulation and antiestrogen resistance in human breast cancer cells. J Biol Chem 2001, 276:40888-40895.

98. Pegram MD, Pauletti G, Slamon DJ: HER-2/neu as a predictive marker of response to breast cancer therapy. Breast Cancer Res Treat 1998, 52:65-77.

99. Slamon DJ, Clark GM, Wong SG, Levin WJ, Ullrich A, McGuire WL: Human breast cancer: correlation of relapse and survival with amplification of the Her-2/Neu oncogene. Science 1987, 235:177-182.

100. Slamon DJ, Godolphin W, Jones LA, Holt JA, Wong SG, Keith DE, Levin WJ, Stuart SG, Udove J, Ullrich A: Studies of the Her$2 /$ neu proto-oncogene in human breast and ovarian cancer. Science 1989, 244:707-712.

101. Newman L, Xia W, Yang HY, Sahin A, Bondy M, Lukmanji F, Hung $\mathrm{MC}$, Lee MH: Correlation of p27 protein expression with HER2/neu expression in breast cancer. Mol Carcinog 2001, 30: 169-175

102. Spataro VJ, Litman H, Viale G, Maffini F, Masullo M, Golouh R, Martinez-Tello FJ, Grigolato P, Shilkin KB, Gusterson BA, Castiglione-Gertsch M, Price K, Lindtner J, Cortes-Funes H, Simoncini E, Byrne MJ, Collins J, Gelber RD, Coates AS, Goldhirsch A: Decreased immunoreactivity for p27 protein in patients with early-stage breast carcinoma is correlated with HER-2/neu overexpression and with benefit from one course of perioperative chemotherapy in patients with negative lymph node status: results from International Breast Cancer Study Group Trial V. Cancer 2003, 97:1591-1600.

103. Lane HA, Beuvink I, Motoyama AB, Daly JM, Neve RM, Hynes NE: ErbB2 potentiates breast tumor proliferation through modulation of p27Kip1-Cdk2 complex formation receptor overexpression does not determine growth dependency. Mol Cell Biol 2000, 20:3210-3223.

104. Bedi A, Zehnbauer BA, Barber JP, Sharkis SJ, Jones RJ: Inhibition of apoptosis by BCR-ABL in chronic myeloid leukemia. Blood 1994, 83:2038-2044.

105. Pendergast AM, Quilliam LA, Cripe LD, Bassing CH, Dai Z, Li N, Batzer A, Rabun KM, Der CJ, Schlessinger J: BCR-ABL-induced oncogenesis is mediated by direct interaction with the $\mathrm{SH} 2$ domain of the GRB-2 adaptor protein. Cell 1993, 75:175-185.

106. Skorski T, Kanakaraj P, Ku DH, Nieborowska-Skorska M, Canaani $E$, Zon G, Perussia B, Calabretta $B$ : Negative regulation of p120GAP GTPase promoting activity by $\mathrm{p} 210 \mathrm{bcr} / \mathrm{abl}$ : implication for RAS-dependent Philadelphia chromosome positive 
cell growth. J Exp Med 1994, 179:1855-1865.

107. Danhauser-Riedl S, Warmuth M, Druker BJ, Emmerich B, Hallek M: Activation of Src kinases p53/56lyn and p59hck by p210bcr/abl in myeloid cells. Cancer Res 1996, 56:35893596.

108. Cortez D, Reuther G, Pendergast AM: The Bcr-Abl tyrosine kinase activates mitogenic signaling pathways and stimulates G1-to-S phase transition in hematopoietic cells. Oncogene 1997, 15:2333-2342.

109. Weng LP, Brown JL, Eng C: PTEN coordinates $G_{1}$ arrest by down-regulating cyclin D1 via its protein phosphatase activity and up-regulating p27 via its lipid phosphatase activity in a breast cancer model. Hum Mol Genet 2001, 10:599-604.

110. Narita Y, Nagane M, Mishima K, Huang HJ, Furnari FB, Cavenee WK: Mutant epidermal growth factor receptor signaling downregulates p27 through activation of the phosphatidylinositol 3-kinase/Akt pathway in glioblastomas. Cancer Res 2002, 62: 6764-6769

111. Yakes FM, Chinratanalab W, Ritter CA, King W, Seelig S, Arteaga CL: Herceptin-induced inhibition of phosphatidylinositol-3 kinase and Akt Is required for antibody-mediated effects on p27, cyclin D1, and antitumor action. Cancer Res 2002, 62: 4132-4141.

112. Gesbert F, Sellers WR, Signoretti S, Loda M, Griffin JD: $\mathrm{BCR} / \mathrm{ABL}$ regulates expression of the cyclin-dependent kinase inhibitor p27 Kip1 through the phosphatidylinositol 3kinase/AKT pathway. J Biol Chem 2000, 275:39223-39230.

113. Murillo $\mathrm{H}$, Huang $\mathrm{H}$, Schmidt LJ, Smith DI, Tindall DJ: Role of $\mathrm{PI} 3 \mathrm{~K}$ signaling in survival and progression of LNCaP prostate cancer cells to the androgen refractory state. Endocrinology 2001, 142:4795-4805.

114. Forti FL, Schwindt TT, Moraes MS, Eichler CB, Armelin HA: ACTH promotion of $\mathrm{p} 27^{\mathrm{Kip} 1}$ induction in mouse $\mathrm{Y} 1$ adrenocortical tumor cells is dependent on both PKA activation and Akt/PKB inactivation. Biochemistry 2002, 41:10133-10140.

115. Mamillapalli R, Gavrilova N, Mihaylova VT, Tsvetkov LM, Wu H, Zhang $\mathrm{H}$, Sun $\mathrm{H}$ : PTEN regulates the ubiquitin-dependent degradation of the CDK inhibitor P27 KIP1 through the ubiquitin E3 ligase SCFSKP2. Curr Biol 2001, 11:263-267.

116. Wirbelauer C, Sutterluty H, Blondel M, Gstaiger M, Peter M, Reymond F, Krek W: The F-box protein Skp2 is a ubiquitylation target of a Cul1-based core ubiquitin ligase complex: evidence for a role of Cul1 in the suppression of Skp2 expression in quiescent fibroblasts. EMBO J 2000, 19:5362-5375.

117. Yang G, Ayala G, Marzo AD, Tian W, Frolov A, Wheeler TM, Thompson TC, Harper JW: Elevated Skp2 protein expression in human prostate cancer: association with loss of the cyclin-dependent kinase inhibitor p27 and PTEN and with reduced recurrence-free survival. Clin Cancer Res 2002, 8: 3419-3426.

118. McManus EJ, Alessi DR: TSC1-TSC2: a complex tale of PKBmediated S6K regulation. Nat Cell Bio/ 2002, 4:E214-E216.

119. Marygold SJ, Leevers SJ: Growth signaling: TSC takes its place. Curr Biol 2002, 12:R785-R787.

120. Soucek T, Yeung RS, Hengstschlager M: Inactivation of the cyclin-dependent kinase inhibitor p27 upon loss of the tuberous sclerosis complex gene-2. Proc Natl Acad Sci USA 1998, 95:15653-15658.

121. Nourse J, Firpo E, Flanagan WM, Coats S, Polyak K, Lee MH, Massagué J, Crabtree GR, Roberts JM: Interleukin-2-mediated elimination of the p27kip1 cyclin-dependent kinase inhibitor prevented by rapamycin. Nature 1994, 372:570-573.

122. Firpo EJ, Koff A, Solomon MJ, Roberts JM: Inactivation of a Cdk2 inhibitor during interleukin 2-induced proliferation of human $\mathrm{T}$ lymphocytes. Mol Cell Biol 1994, 14:4889-4901.

123. Catzavelos C, Bhattacharya N, Ung YC, Wilson JA, Roncari L, Sandhu C, Shaw P, Yeger H, Morava-Protzner I, Kapusta L, Franssen E, Pritchard KI, Slingerland JM: Decreased levels of the cell-cycle inhibitor $\mathrm{p} 27^{\mathrm{Kip} 1}$ protein: prognostic implications in primary breast cancer. Nat Med 1997, 3:227-230.

124. Porter PL, Malone KE, Heagerty PJ, Alexander GM, Gatti LA, Firpo EJ, Daling JR, Roberts JM: Expression of cell cycle regulators p2 $7^{\mathrm{kip} 1}$ and cyclin $\mathrm{E}$, alone and in combination, correlate with survival in young breast cancer patients. Nat Med 1997, 3:222225.

125. Loden M, Nielsen NH, Roos G, Emdin SO, Landberg G: Cyclin E dependent kinase activity in human breast cancer in relation to cyclin E, p27 and p21 expression and retinoblastoma protein phosphorylation. Oncogene 1999, 18:2557-2566.

126. De Paola F, Vecci AM, Granato AM, Liverani M, Monti F, Innoceta AM, Gianni L, Saragoni L, Ricci M, Falcini F, Amadori D, Volpi A: p27/kip1 expression in normal epithelium, benign and neoplastic breast lesions. J Patho/ 2002, 196:26-31.

127. Moriya T, Sakamoto K, Sasano H, Kawanaka M, Sonoo $H$, Manabe T, Ito J: Immunohistochemical analysis of Ki-67, p53, p21, and p27 in benign and malignant apocrine lesions of the breast: its correlation to histologic findings in 43 cases. Mod Pathol 2000, 13:13-18.

128. Reed W, Florems VA, Holm R, Hannisdal E, Nesland JM: Elevated levels of p27, p21 and cyclin D1 correlate with positive oestrogen and progesterone receptor status in node-negative breast carcinoma patients. Virchows Arch 1999, 435:116-124.

129. Soslow RA, Carlson DL, Horenstein MG, Osborne MP: A comparison of cell cycle markers in well-differentiated lobular and ductal carcinomas. Breast Cancer Res Treat 2000, 61:161-170.

130. Gillett CE, Smith P, Peters G, Lu X, Barnes DM: Cyclin-dependent kinase inhibitor $\mathrm{p} 27^{\mathrm{Kip} 1}$ expression and interaction with other cell cycle-associated proteins in mammary carcinoma. $J$ Pathol 1999, 187:200-206.

131. Tsuchiya A, Zhang GJ, Kanno M: Prognostic impact of cyclindependent kinase inhibitor $\mathrm{p} 27^{\mathrm{kip} 1}$ in node-positive breast cancer. J Surg Oncol 1999, 70:230-234.

132. Wu J, Shen A-A, Lu JS, Jiang M, Han Q-X, Fontana JA, Barsky SH, Shao Z-M: Prognostic role of $\mathrm{p} 27^{\mathrm{Kip} 1}$ and apoptosis in human breast cancer. Br J Cancer 1999, 79:1572-1578.

133. Barbareschi M, van Tinteren $H$, Mauri FA, Veronese $S$, Peterse $H$, Maisonneuve P, Caffo O, Scaioli M, Doglioni C, Galligioni E, Dalla PP, Michalides R: p27 kip $^{1}$ expression in breast carcinomas: an immunohistochemical study on $\mathbf{5 1 2}$ patients with long-term follow-up. Int J Cancer 2000, 89:236-241.

134. Leong ACK, Hanby AM, Potts HWW, Tan DSP, Skilton D, Ryder K, Harris WH, Liebmann RD, Barnes DM, Gillett CE: Cell cycle proteins do not predict the outcome in grade I infiltrating ductal carcinoma of the breast. Int J Cancer 2000, 89:26-31.

135. Chappuis PO, Kapusta L, Begin LR, Wong N, Brunet JS, Narod SA, Slingerland J, Foulkes WD: Germline BRCA1/2 mutations and $\mathrm{p} 27^{\mathrm{Kip} 1}$ protein levels independently predict outcome after breast cancer. J Clin Oncol 2000, 18:4045-4052.

136. Leivonen M, Nordling S, Lundin J, von Boguslawski K, Haglund C: p27 expression correlates with short-term, but not with longterm prognosis in breast cancer. Breast Cancer Res Treat 2001, 67:15-22

137. Barbareschi M, Caffo O, Doglioni C, Fina P, Marchetti A, Buttitta F, Leek R, Morelli L, Leonardi E, Bevilacqua G, Dalla Palma P, Harris AL: p21WAF1 immunohistochemical expression in breast carcinoma: correlations with clinicopathological data, oestrogen receptor status, MIB1 expression, p53 gene and protein alterations and relapse-free survival. $\mathrm{Br} J$ Cancer 1996, 74: 208-215.

138. Polyak C, Lee $M H$, Erdjument-romage $H$, Koff $A$, Roberts J, Tempst $\mathrm{P}$, Massagué J: Cloning of p27 KIP1, a cyclin-dependent kinase inhibitor and a potential mediator of extracellular antimitogenic signals. Cell 1994, 78:59-66.

\section{Correspondence}

Joyce Slingerland, Braman Breast Cancer Institute, Sylvester Comprehensive Cancer Center, University of Miami School of Medicine, 1475 NW 12th Avenue (D8-4), Miami, FL 33136 USA. Tel: +1 305243 6788; fax: +1 305243 4787; e-mail: e-mail: jslingerland@med.miami.edu 